\title{
Training for Independence in Learning
}

\author{
Maureen Sawkins
}

\footnotetext{
If English as a Second Language students are going to compete with native speakers for jobs and in educational programs, they need to know how to help themselves learn more effectively. Helping students in "how to learn" requires the teachers to show leadership in training them to become good language learners. Learner training is advocated to help them maximize their learning
}

opportunities both inside and outside the classroom, and prepare them for continued learning on their own after their language course is over. This article suggests some basic principles in implementing learner training, areas students most need help with in becoming more independent, and some materials and activities which can foster the strategies needed.

\section{RATIONALE}

\section{Learner Training - What? and Why?}

Teachers know very little about their students' beliefs regarding how language is learned or the source of those beliefs. Yet these beliefs shape the system that the learner uses to accomplish the enormous task of learning a new language. Self reports indicate that strategies are the tools used to deal with the problems the learner faces in learning a new language. Selecting the right strategies and applying them correctly is fundamental to success in language learning. Furthermore, having a systematic approach enables the learner to take on responsibility for his ${ }^{1}$ own language learning with the ultimate goal of becoming autonomous. Yet in most second language programs, learners get little or no training in how to learn most effectively.

An analogy can be drawn between learner training and teacher training. Without teacher training a new teacher would use the methods by which she had been taught. Then slowly, through trial and error, she would discover what worked and what did not in her particular situation with her particular students. Teacher training would expedite her acquisition of methods and techniques, give her background information on why some were more effective than others, and help her discover her personal teaching style. Furthermore, it would give her tools for planning her 
lessons, monitoring how she was doing, and evaluating the outcome of her teaching. Knowledge and practice as well as exposure to other teachers' ways and means would help her develop the ability to transfer her skills to other teaching situations.

An administrative nightmare is the teacher who receives a negative evaluation, then screams, "What do you mean? I've been teaching for 27 years!" Number of years of experience is no guarantee of good teaching. Teacher training, inservice training and personal professional development are also needed for the development of good teaching strategies.

Similarly, learners should not be thrown into a classroom and be expected to perform well, without training in learning how to learn a language. Students bring to the language learning classroom the learning styles that they have developed from their previous educational backgrounds. While these may be appropriate for some tasks, they may be totally inappropriate for others. Students in their second language learning programs should be provided with opportunities to explore their personal styles, discover and practice new strategies for learning, and finally, they should learn to apply these new "tools for learning" in other situations so that they can take responsibility for their own learning and become truly autonomous learners.

In this paper, learner training will be used to describe a learning situation in which the teacher plays an instrumental role in helping the learners discover how to learn effectively so that they can make the most of their language learning situations both inside and outside of the classroom. Learners must learn how to do for themselves what teachers typically do for them in the classroom. Wenden (1985a) says learner training provides a systematic approach to helping them develop and refine their innate learning competence. This includes raising and refining awareness about various aspects of their learning processes, and expanding their repertoire of strategies. The term should not be understood in a narrow sense as the rote teaching of discrete behaviours. Learner training advocates say that learners should be helped to learn how to learn, and how to make the most of the learning opportunities that are available to them in the environments in which they find themselves, so that they can carry on learning independently after their course is finished.

A great deal is known about the characteristics of good language learners and the processes they use while learning a language. It is necessary to share what is known about language acquisition with the learners. It is also necessary to learn what it is they do to help themselves, encourage them to share their personal strategies with each other, and as well, train them in those cognitive, metacognitive, communicative and practice strategies which will allow them to become truly independent language learners. 


\section{Learner Training - How Much? and When?}

Learner training has been suggested for some time, to help learners become more independent, but it is interesting to note the changes of emphasis through the years. Rubin (1975) suggested that learning strategies, after enough research had been done on them, should become incorporated into methodology. She advised teachers to attend to the learning process more and to tailor their input to their students' needs, thereby providing students with techniques that would enable them to learn on their own. At that time, Rubin was examining how the teacher could transmit knowledge about learner strategies to the learner. Schumann and Schumann (1977) suggested that a learner education program might include a course in second language acquisition, which would inform the learner of the nature of his task in non-technical language: "The goal of the course would be to dispel myths about Second Language Learning which the learner may hold and which may be counterproductive." Naiman, Frohlich, Stern and Todesco (1978) recommended a cautious teaching how-to-learn approach. Inventories of strategies and techniques could form the basis of awareness discussions on the ways of language learning.

Hints from the teacher or periodical brief exchanges with students about different ways of learning would change classroom language learning from a fairly mechanical routine into a more deliberate co-operative undertaking. Different approaches to learning could be planned and tried out in a more conscious way than has been customary. (1978:103)

Earl Stevick (1981) raised the question of whether the ways of the good language learner could be taught to poor language learners at all. He felt that the varieties in learning styles might be of such a nature that different learning strategies could not easily be taught. Recently, there have been learner-centered approaches which involve the learners in the decisionmaking, planning, organization and direction of their language courses in order to encourage them to take more control over the management of their own study both inside and outside the classroom. Littlejohn (1983) recommended a very gradual and cautious approach to increasing learner involvement.

They must be helped to an understanding of the nature of language and language learning, and how their language course is being conducted through especially designed activities. (1983:600)

The present and future directions seem to point towards more direct teacher intervention in learning strategies. Sinclair and Ellis (1985), O'Malley et al. (1985) and Wenden (1985a \& 1985b) advocate an active approach to learner training for learner autonomy. In some programs, 
courses have been developed specifically to train learners in awareness and strategies. In other situations, learner training is being integrated into language teaching. In either model it is recommended that the strategy training by teachers move through stages, decreasing the amount of teacher control, so that learners gradually take on more responsibility for their own learning.

\section{The Interplay of Attitude and Strategy Use}

The importance of a positive attitude to successful language learning has always been recognized. Savignon (1976) said that attitude is the single most important factor in second language learning. Naiman, Frohlich, Stern and Todesco (1978) suggested that a positive attitude to language learning appears to be a necessary but not a sufficient condition for success. They also felt that positive attitudes as determining factors of success were most important at the initial stages. Attitude and strategy use are reflected in factors such as motivational intensity. Gardner and Smythe (1975) have argued that attitude will determine the extent to which language learners engage in particular supplementary activities; in this case, these activities are represented by the degree to which the learning strategies are employed. Given these facts and if, as Bialystok (1978:69-83) says, affective variables are amenable to pedagogical modification, then it is reasonable to suggest that learner training in strategy use should be provided at new intake time while motivation is high, rather than left until a point when the successful language learners have risen to the top of the pile and the unsuccessful are left in need of extra help. At this point, introducing learner training for the unsuccessful would probably meet with a great deal of resistance. Saying, "Look, this is what the good language learner does and it works for him" would probably not persuade him to abandon ineffective ways, and he would only become more discouraged and further lose interest.

\section{Learner Training - How?}

The question that now arises is how to train learners to learn more effectively, accept responsibility for their own learning, and thus become independent language learners. First and foremost, teachers need to be aware of learner characteristics and language learning strategies. O'Malley et al. (1985), in studying the range and frequency of learning strategy uses by students learning E.S.L., interviewed 53 teachers regarding their instructional approaches and understanding of students' learning processes. They asked teachers if they provided instruction in learning strategies for any of nine language activities or if they had observed students 
using strategies for any of the activities on their own. In general, the strategies identified by the teachers were teaching strategies, and most teachers indicated that they were unacquainted with learning strategies. While it would be dangerous to generalize from this data, it is apparent that teachers must be well read in language acquisition and have a healthy interest in the language learning processes of their students in order to develop a process approach to their teaching. Furthermore, knowledge of learner factors and how they affect language learning should help the teacher see that students cannot be expected to respond alike to teaching. Also, teachers should then be able to help students analyze their own characteristics and adjust their learning as far as possible to what they know about themselves.

Assuming that teachers are interested and prepared to attempt some learner training, there are four broad guiding principles for this.

1. The teacher should foster a tactical attitude. In all aspects of teaching, the teacher can help the students to see language learning as problem solving, and encourage an adventurous, risk-taking and experimental approach.

2. The teacher should make strategies explicit. Through talking about strategies, practising activities which bring strategies to conscious awareness level, and sharing with other students, strategies can be made explicit. Exercises in self-discovery and identifying personal strategies can be integrated into many other language learning activities.

3. The teacher should be aware of different styles of learning. She should recognize and point out to students that there are many ways to learn, although some may be more effective than others.

4. The teacher should teach for transfer. The problem is the same for learning strategies as for thinking skills. Many learners do not carry over principles to other contexts. The same strategies must be practiced in varied contexts to help the learner generalize. A strategy that works successfully for a learner in the language laboratory on a listening exercise, for example, may also be appropriate in a real life telephoning situation.

Another area for teachers to consider is what their students need help with, so that they can plan effectively. Sinclair and Ellis (1985), in this model of learner training for learner autonomy, suggest eight areas for learner training.

1. Self-awareness - helps the learners to be aware of their selves, attitudes and feelings towards language learning and using the language.

2. Language awareness - helps the learners to have insight into their 
learning problems, and research is shared from teacher training courses.

3. Language needs and goals - trains the learners to set learning goals.

4. Preparation and organization - helps the learners to discover the value of organizing their learning and how to do it.

5. Risk-taking - helps the learners to take a more adventurous approach in such things as guessing, predicting, and so on.

6. Personal strategies - encourages the learners to experiment and find those which are appropriate for them.

7. Self-assessment - encourages the learners to check up on how well they are doing and record the results of their self-assessments so that they can recognize their progress, and thus be motivated to continue.

8. Preparation for autonomy - helps learners to schedule their own learning, maximizing contact with the target language.

\section{IMPLEMENTATION: TECHNIQUES \& ACTIVITIES}

In implementing learner training it is necessary to decide in which areas to help the learners become more independent, and then to develop materials and activities which foster the strategies needed. Activities for learner training can be grouped into five categories. First, those that promote awareness of self and language; second, those that promote good self-management practices; third, those that aid in the area of specific task learning; fourth, those that provide for global practice opportunities; and fifth, those that provide opportunities for dealing with communication breakdown. By working on their strategies in these five areas, it is possible that learners may incorporate some or all of the characteristics of the good language learner into their personal learning styles.

\section{Activities for Self and Language Awareness}

Activities which promote introspection should be included to encourage learners to look at their own language learning processes. One possibility might be to encourage reflections in their daily journals on what they had learned, methods they had used in learning or practising language, successes and failures, and their feelings involved. In responding, teachers could make suggestions and then later ask students if they had tried them out. This would bring out an awareness of learners' personal variables which promote or inhibit individual language learning. The goal would be for the learner to use the journal information to minimize the inhibiting aspects of these variables. Another possibility for promoting introspection about language learning processes might be problemsolving activities. The focus could be language learning problems set in 
hypothetical situations, and students could be asked to brainstorm on solutions with discussion following. Quotes from other language learners could similarly be a focus for discussion. After discussion, which would include identification of language learning strategies, their effectiveness, and individual differences, the teacher could share some findings about what is known about language acquisition and the good language learner. Composition topics which invite the learner to reflect on his language learning processes could follow naturally from this. These would yield information which could then be shared among the members of the class. Readings could be chosen which focus in on language learning to help in developing the students' awareness of the "what" and "how" of language learning. Wenden (1985a) mentions that she has adapted for her class parts of the manual How to be a More Successful Language Learner written by Joan Rubin and Irene Thompson (1982). Questionnaires which ask questions about learning English could be answered by learners at the beginning of the course, the results compiled, and then used as a basis for discussion. The purpose of the questionnaires would be to demonstrate from the beginning that the students' experiences and opinions were to be drawn upon, and to encourage them to consider ways of learning and strategy use.

This author has found that allowing students to self-select their own reading materials in a controlled setting and then asking them to reflect on, justify their choices, tell if they learned anything new in the way of information or language, and give an opinion on what they read, heightens their awareness and increases their sense of commitment to their own language learning. Having to share orally their articles with other group members in the class opens their eyes to other students' interests, strategies and points of view.

\section{Activities for Self-Management}

Activities which teach learners to plan for, monitor, and evaluate their own language learning should be included in learner training. Planning could include organizing for learning, deciding what comes first and setting goals. It could also include making decisions regarding resources and strategies that could be used to learn. Littlejohn (1983) suggests that students at an intermediate level and up can be asked to evaluate textbooks. Students in his class were split into small groups, and each allotted sections of grammar work from their last textbook. They were then asked to examine each section in terms of what it required them to do and how difficult or easy they found it. The results of the group discussions were collected and a list of areas of grammar was drawn up in descending order of difficulty. The purpose was to train students to think actively about 
what a text was trying to accomplish, and whether it was appropriate for their personal language learning needs and their proficiency levels. Independence in language learning is a long-term goal, and being able to choose suitable materials for self-study is a necessary first step. Littlejohn also invited his students to research an area of grammar, present their findings to the group as a whole, and provide exercises, tasks, games, and other activities for practice. The teacher provided reference materials, but sat amongst the students and only provided assistance when called upon to do so. The purpose was to encourage students to think more deeply about organizing their own learning.

Unlike planning strategies which are for the future, monitoring strategies are used to oversee what is actually "on-line". Monitoring for language error is difficult, and the danger in overuse well documented (Krashen 1978). However, second language learners need to monitor their processes for obstacles or problems that inhibit learning. The feelings evoked in certain situations are examples of such problems, and identifying them and understanding their inhibiting effect can be a useful first step towards managing them. Monitoring language learning also means checking up to see that the system of study meets with the goals which the learners have set for themselves. The teacher needs to encourage learners to ask themselves continuously "Where am I now?" Another useful monitoring strategy can be the using of peers as a resource. Students can verify each other's accuracy, fill in gaps in information and clarify areas of confusion. Encouraging learners to make use of each other actively as resources and draw on the teacher only when necessary will move them towards independence.

Closely allied to monitoring is the all important area of self-evaluation. Sinclair and Ellis (1985) say that the biggest problem is the learner's attitude that the responsibility for evaluating performance and progress lies only with the teacher. Teachers need to encourage learners to ask themselves "How well did I do?", and to record the results of their self-assessment. It is necessary to show the link between self-evaluation and motivation. Simple pre- and post tests, charts and completed work, study schedules, and personal progress records can be quite useful for learners in checking up on how well they are doing. Moreover, they are excellent preparation for autonomy in language learning.

Thus, the classroom provides many opportunities for teaching these self-management strategies, but it is crucial that they be made explicit. For example, when a teacher pauses to review and answer student questions, she can talk about self-review and the role that self-testing can play in both consolidating new learning and identifying areas of misunderstanding or confusion. Explaining how this teaching strategy can be used as an individual learning strategy by each student and why it is helpful would 
not take very much time away from language learning activities. The announcement of a class test is an excellent time to present strategies for test preparation or discuss negative and positive self-talk for coping with test anxiety. When a teacher is developing her teaching strategies, she should also think about how these can be made explicit and how students can be taught to incorporate them into their own study activities. Many exposures will be necessary in a variety of contexts, and will have to be given by a variety of teachers before learners will use unfamiliar learning strategies and develop a new sense of responsibility for their own learning.

\section{Activities for Focused Task Learning}

Here, more than in any other area, learners need to discover the most effective strategies for their personal learning styles. When faced with a specific language learning task, different learners tackle it in different ways. It is necessary to recognize that there may be different ways of successfully mastering this task; nevertheless, an active, experimental and tactical approach should be encouraged by the teacher for all learners.

Learners must focus their attention on certain aspects of incoming information in order to get the meaning out of it that they need. They must practice strategies for listening, observing or reading selectively, keeping in mind what it is they wish to learn. Knowles (1975) says an independent reader knows what he wants from a resource book, and probes until he gets it. He suggests that learners can be trained for selective reading. Giving students a variety of reference books, a teacher can have them read the covers to discover the purpose of the book, gather information on the author, and so on. They can then be instructed to read the introduction, foreword or preface for the author's or editor's point of view. After that they can read the table of contents to see how it is organized. At this point students can be asked to think of a question about something they have become curious about. By examining their question they can pick out a key word or phrase to look up in the index, or if it is not there, to think of a synonym. If that also is not there, perhaps the table of contents can lead to the page of the book where the question can be answered, or at least more leads can be discovered which can then be followed. In this way, learners can be trained in the valuable use of advanced organizer strategies for learning, as well as in how to use reference books. Afterwards, analysis by the group can help in developing the awareness of how to get information out of reference texts, and the necessity of deciding beforehand what needs to be known.

Language learners need to practise using strategies to make input 
comprehensible. Rubin (1983) refers to this type of cognitive strategy as inductive inferencing and lists clues such as looking at actions, pictures or other visuals, attending to key words, intonation, conversational sequence, parts of words, and topic and context of discourse as aids in comprehension. Authentic reading materials such as newspapers, science texts or any other content-based material can be useful for practising strategies of inductive inferencing for meaning, but before authentic materials can be used effectively, there must be practice with prepared materials which utilize and make explicit these strategies. For listening practice, T.V. shows, films, or video-taped materials can be used in the same way after the sequences of listening strategies have been practiced in class with prepared materials. Another way of getting information from incomprehensible input is to ask questions. Learners should be involved in activities that require them to practice asking their peers, teachers, or native informants for information regarding language learning. Learners also need practice in looking for patterns and relationships in language use in classroom situations so that they can look for them outside in a wider variety of situations. Rubin says that learners use deductive reasoning when they compare languages they know, use analogies and look for similarities.

Learners need to practise activities which will help them in retaining for future use what they have understood. Earl W. Stevick (1982) discusses memorization which he defined as working on a body of material until one is able to reproduce it word for word on demand. For people who do not mind doing it, memorization can be a learning activity which greatly expedites the kinds of experiences which promote acquisition of language. Whole sentences can be used exactly as they stand: "How much is it?" Other sentences which are less likely to come up in real-life conversation, may still serve as handy models for what students want to say at some other time. "Can you tell me where the cafeteria is?" may serve as a handy model when a student needs to ask where the bus station or washroom is. Three well recognized techniques that learners use are repeating, associating or categorizing the material in order to aid in its retention. Teachers must incorporate opportunities for practising these strategies for memorization in everyday language lessons. Strategies for triggering the release of this stored information are necessary too. Sometimes language learners cannot easily recall words they want to use. They may wait for the term to appear or try to remember it by using some association. Faerch and Kasper (1983) found that learners in these situations (i) said out loud words with similar meanings; (ii) thought of a word in their target language that was somewhat the same in form or sound; (iii) remembered the situation where the word was used or written; or (iv) used sensory procedures. 


\section{Activities for Global Practice}

The quality of the language environment is of paramount importance to success in learning a new language. In teaching immigrants or foreign students in the ESL setting, there should be plenty of opportunities for practice if they will only avail themselves of the informal or natural learning environment. Krashen (1981) claims that exposure to natural communication in the target language is necessary for the subconscious processors to work well. The richer the learners' exposure to the target language, the more rapid and comprehensive the learning is likely to be.

Global practice activities allow for open-ended practice by providing the learner with opportunities to develop facility and fluency in the use of the second language. Moreover, the full responsibility for language teaching does not fall only on the shoulders of teachers in classrooms. Ordinary people with whom the learner interacts while living and working in the community, manifest teacher-like behaviour by modifying their speech in a variety of ways to make it easier for the learner to understand their talk and thus learn the language. D'Anglejan (1978) says that direct participation in communication with native speakers provides the authentic input data, feedback on performance and the psychological support which are the prerequisites for second language acquisition.

Wenden (1985b) states that learners she interviewed stated they used the following types of resources for global practice: people (people on the street, in bus lines, special friends, casual friends, children); living arrangements (family, single friend, campus dorm); media (T.V., radio, newspaper); classes (in their second language relating to personal or professional interest); routine activities (shopping, post office); leisure time interest (swimming, parties); work (interacting with clients or coworkers, reading documents).

Contact assignments, in which learners prepare for and carry out language-using activities in situations outside the classroom can give valuable feedback on their ability to communicate in the real world. Assignments such as obtaining or giving information, making transactions, following directions or simply observing what people say or do in certain situations create opportunities for learners to generate comprehensible input from native speakers. Varied and repeated practice is important to help learners generalize to other situations. A further benefit in contact assignments is that they help the student be a little less shy in seeking out contacts with native speakers of the target language, and this puts him in the valuable position of getting more global practice.

Utilizing the media for global practice is a favoured way of increasing exposure to the target language for the good language learner. Teachers must first find out what the learners can and do watch, listen to or read, 
and then incorporate this into their teaching programs. It is not enough to say "Watch T.V." or "Listen to the radio.", as these take a great deal of effort, and will probably not be done despite the best of intentions. T.V. and radio schedules as well as newspaper indexes should be made familiar to learners. Homework assignments can involve listening or reading for something specific and then bringing back information on it. The video cassette recorder can be used to capture authentic communication and then the material reviewed for clues to meaning in the linguistic, paralinguistic and extra-linguistic features of the discourse. In class, the teacher can get students to watch the video without the sound and try to guess what is going on from the para- and extra-linguistic signals. Once again, probably the most valuable benefit is that the learners will become more familiar with the media, discover some things they may enjoy, and therefore be a little less reluctant to avail themselves of the global practice the media offers.

\section{Activities for the Management of Communication}

Communication strategies are useful in the area of training for preparedness. If students see that communication gaps and breakdowns occur with everybody, and have a ready and willing attitude to try ways to continue communicating as well as a handy repertoire of communication strategies to fill the gaps, they will be more adventurous in trying language in unfamiliar settings. In the classroom, the use of communication strategies should never be inhibited as non-linguistic, because the use of them replicates the natural communication process in which the participants may not hear or properly understand what is said, and so must guess from the other clues around them, living with uncertainty until they find out.

Sinclair \& Ellis (1985) suggest that videos of second language learners miscommunicating, or failing to communicate can be used in a positive way. The interaction can be analyzed and strategies can be suggested for dealing with the situation. Videos can be double-recorded, showing a 'right way' and a 'wrong way'. Take 1 might show miscommunication or failure to communicate, and then the embarassed speaker slinking away, followed by Take 2 showing the same scene, but using more successful communication strategies to get him through the problem and keep the interaction going. Students could then prepare role-plays of similar situations.

\section{CONCLUSION}

Learner training can be part of a teacher's repertoire. In the beginning, control should be tight and training should involve all aspects of stragegy 
use; however, there should be a gradual withdrawal of teacher control in order to allow students to take on some of the responsibility for management of their own learning. For as surely as the sun sets in the West, students will complete their language learning classes and leave their teachers behind them. When that time comes, they need to be well prepared to carry on learning on their own.

\section{FOOTNOTES}

1. Teacher will be referred to as she/her.

Student will be referred to as he/him.

\section{REFERENCES}

Bialystok, Ellen. (1978). A theoretical model of second language learning. Language Learning. Vol. 28, No. 1. 69-83.

D'Anglejan, Alison. (1978). Language learning in and out of classrooms. In Understanding Second and Foreign Language Learning. Jack Richards (Ed.). Rowley, Mass.: Newbury House.

Faerch, C. \& F. Kasper. (1983). Strategies in Interlanguage. London: Longman.

Gardner, R. C. \& P. C. Smythe. (1975). Motivation and second language acquisition. Canadian Modern Language Review. Vol. 31. 218-34.

Knowles, Malcolm. (1975). The Self-Directed Learner. Chicago: Follett Publishing Company.

Krashen, Stephen D. (1978). The monitor model for second language acquisition. In Second Language Acquisition \& Foreign Language Teaching. Rosario Gringas (Ed.). Arlington, Virginia: Center for Applied Linguistics. 1-26.

-. (1981). Second Language Acquisition and Second Languae Learning. Oxford: Pergamon Press.

-. (1982). Principles and Practices in Second Language Acquisition. Oxford: Pergamon Press.

Littlejohn, A. P. (1983). Increasing learner involvement in course management. TESOL Quarterly. Vol. 17., No. 4. 600, 602-3.

Naiman, N., M. Frohlich, H. H. Stern, and A. Todesco. (1978). The Good Language Learner. Toronto: The Ontario Institute for Studies in Education, 66, 103.

O'Malley, J. M., A. U. Chamot, G. Stewner-Manzanares, R. P. Russo, and L. Kupper. (1985). Learning strategy applications with students of English as a second language. TESOL Quarterly. Vol. 19., No. 3. 66, 557-84.

Rubin, J. (1975). What The Good Language Learner can teach us. TESOL Quarterly. Vol. 9., (No. 1.), 41-51.

- (1983). What have we learned about learner strategies? Paper presented at the TESOL Convention (Toronto). To appear in A. Wenden \& J. Rubin (Eds.) Learner Strategies: Implications for the Second Language Teacher and Researcher. Oxford: Pergamon Press.

Rubin, J. \& I. Thompson. (1982). How to be a More Successful Language Learner. Boston, Mass.: Heinle \& Heinle. 
Savignon, S. (1976). On the other side of the desk: A look at teacher attitude \& motivation in second language learning. Canadian Modern Language Review. Vol. 32., 295-302.

Schumann, F. M. \& J. H. Schumann. (1977). Diary of a language learner: An introspective study of second language learning. On TESOL'77. (Eds.) H. D. Brown, C. Yorio \& R. Crymes. TESOL: Wash. D.C. 248.

Sinclair, B. \& G. Ellis. (1985). Learner training: Preparation for learner autonomy. Audiocassete. Paper presented at the TESOL Convention. New York, N.Y. March 1985.

Stern, H. H. (1975). What can we learn from The Good Language Learner? Canadian Modern Language Review. Vol. 31.

Stevick, E. (1981), Learning a foreign language: The natural ways. ON TESOL '81. (Eds.). M. Hines \& W. Rutherford. TESOL: Wash. D.C. 8-9.

- (1982). Teaching and Learning Languages. Cambridge: Cambridge University. 50-81.

Wenden, A. (1985a). Facilitating learner competence: Perspectives on an expanded role for second-language teachers. Canadian Modern Language Review. Vol. 41. 981-90.

—. (1985b). Learner strategies. TESOL Newsletter. Vol. 19, No. 5, 1-7.

\section{THE AUTHOR}

Maureen Sawkins holds a B.A. and a M.Ed. in ESL from University of British Columbia. She has worked in libraries, set up and co-ordinated ESL Learning Centres and taught ESL for 17 years. She is currently the Advanced Co-ordinator in the ESL Half-time Department at Vancouver Community College, King Edward Campus. She has developed materials for independent study on local topics of interest, Preparation for Citizenship, and Easy Readers for an adult literacy project. 